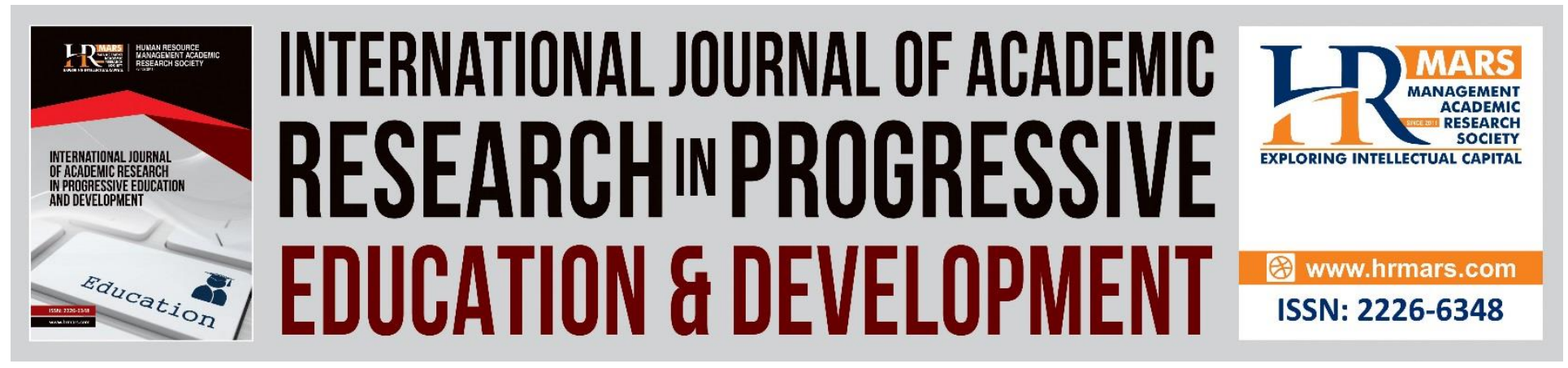

\title{
Students' Perception of Lecturers' Performance at The International Islamic University Malaysia, Department of Business Administration
}

\author{
Mohammed Bawah, Zaireena Wan Nasir
}

To Link this Article: http://dx.doi.org/10.6007/IJARPED/v10-i2/9723

DOI:10.6007/IJARPED/v10-i2/9723

Received: 15 February 2021, Revised: 20 March 2021, Accepted: 08 April 2021

Published Online: 21 April 2021

In-Text Citation: (Bawah \& Nasir, 2021)

To Cite this Article: Bawah, M., \& Nasir, Z. W. (2021). Students' Perception of Lecturers' Performance at The International Islamic University Malaysia, Department of Business Administration. International Journal of Academic Research in Progressive Education and Development, 10(2), 49-66.

Copyright: (C) 2021 The Author(s)

Published by Human Resource Management Academic Research Society (www.hrmars.com)

This article is published under the Creative Commons Attribution (CC BY 4.0) license. Anyone may reproduce, distribute, translate and create derivative works of this article (for both commercial and non-commercial purposes), subject to full attribution to the original publication and authors. The full terms of this license may be seen at: $\underline{\text { http://creativecommons.org/licences/by/4.0/legalcode }}$

Vol. 10(2) 2021, Pg. 49 - 66

http://hrmars.com/index.php/pages/detail/IJARPED

JOURNAL HOMEPAGE

Full Terms \& Conditions of access and use can be found at http://hrmars.com/index.php/pages/detail/publication-ethics 


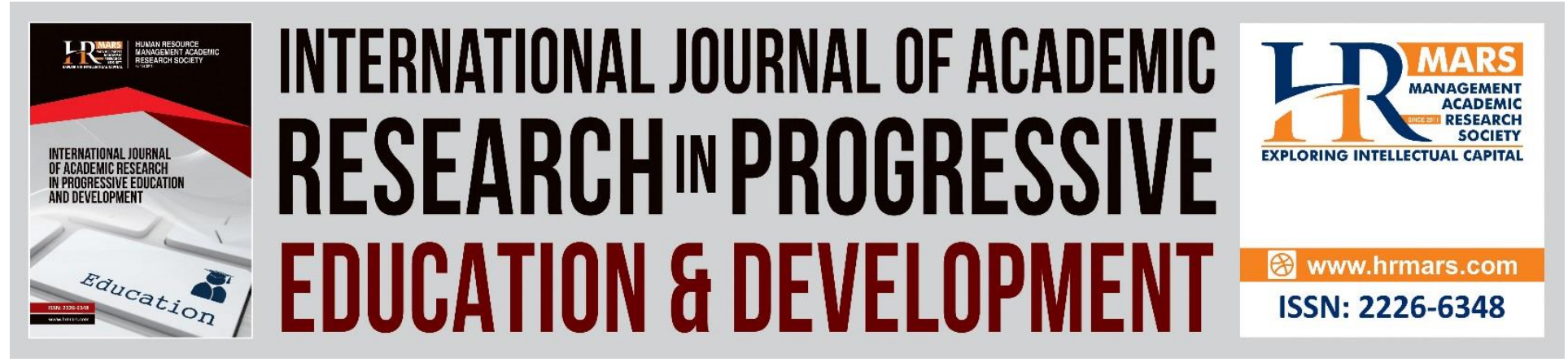

\title{
Students' Perception of Lecturers' Performance at The International Islamic University Malaysia, Department of Business Administration
}

\author{
Mohammed Bawah, Zaireena Wan Nasir \\ IIUM Malaysia
}

\begin{abstract}
This study investigated the impact of students' perception on lecturers' performance in class. The aim of the study was to assess lecturers' performance in lecturing various courses using students' perception as an indicator of lecturers' performance. The study utilized a random sampling research design method with the target population of third and fourth year students. Stratified sampling technique was used to arrive at the study sample of 100 students. A specifically designed instrument, the Students' Perceptions of Performance Scales (SPTPS) was used to gather data. The exploratory factor analysis and confirmatory factor analysis methods were conducted to validate the performance constructs. The results of the analysis shows that, the relationship between the attitude of lecturers and performance in class and the relationship between methodology and lectures' performance in class are all positive. However, the study rejected relationship between knowledge of lecturers and lecturers' performance in class. The study therefore, concluded that, there are aspects of lecturers' performance in class that are less than excellent and in need of further improvement.
\end{abstract}

Keywords: Students' Perception, Lecturers' Performance, IIUM

\section{Introduction}

According to Wachtel (1998) evaluating the performance of lecturers by students started in the early 90's. Cahn (1986) indicated that, the informal assessment of students lecturers also started in 1960's college students. This idea of student assessing their lecturers became accepted by almost all universities worldwide and is probably one of the sources of getting information about lecturers performance in the class

Lecturers play an important role in providing education to students. Lecturers do not only transmit cognitive knowledge, but they also serve as advisors, counsellors and observers to students activities on campus. Van-Rensburg et al, (1993) argue that, it is the duty and responsibility of lecturers to supervise students work, and to provide meaningful and useful feedback. It should be a prime concern for lecturers to generate and discover new ideas through 
academic activities and research. Bandura (1997) asserted that, lecturers are hard working and dedicated to their work in the classroom and they also try their possible best to publish their academic papers, serve on various committees and also work to meet the academic needs of their students.

On the other hand, university students require lecturers to be emotionally stable, experts in their field and be orderly and well prepared. Students fancy lecturers who are knowledgeable, effective, compassionate, and behave in a manner that is socially acceptable to them (Vrey, 1993). Therefore, lecturers know what will appease or anger their students. Students for instance, are happy with lecturers who treat them equally as humans and also make them think in class. Conversely, students hate lecturers who are incompetents, bossy in class, self-centered, treat them unequally as humans in class and partial in giving grades (Goulden et al., 1997).

In fact, students observe whatever goes on in the classroom throughout the course of study in the university, therefore, using students' to assess and evaluate their lecturers should be taken seriously by both lecturers and administrators. The outcome of students' assessment of their lecturers are advantageous to the department and the university as a whole. With such results from students, lecturers are able to understand the mindsets of the students, their abilities and their perception of lecturers' course content and teaching methods (MacGregor, 1993). Students evaluating their own lecturers will enhance lecturers' teaching skills as well as help them to come to the classroom well prepared to deliver.

The assessments of students' should also serve as a useful tool to be used in matters such as renewal of contracts, appointments and promotions (Morton, 1997). The students' evaluation results will also assist students at the beginning of the academic year to decide on which course to take from lecturers. According to Smit (1998) students assessment provide students a sense of control in the course which can lead to positive responses such as improved and increased learning. Machina (1997) observed that, the quantity and quality of students performance will be enhanced significantly if the students have some control over their education.

In the universities, lecturers should have an idea about their method of teaching in the classroom is effective and whether the strategies or styles used are well received by students. One of the surest way of measuring the teaching effectiveness of lecturers is to evaluate the course by the recipients of the knowledge, which is often carried out at every year at the end of each semester. Over the years, assessment of lecturers were done at the end of a particular course in a semester where students were submitted with questionnaires by the lecturer to be filled in the classroom and for onward submission to Quality Assurance division for analysis. The most recent development in the school (IIUM) is the assessment of lecturer via internet through the student portal, making assessment very easy and appropriate without a student or a particular class being harassed by the lecturer concerned for low ratings. This study is concerned mostly with the students' perception of lecturers' performance taking the course lecturer as the study by the school's staff positions which are Professor, Associate Professor, Assistant Professor, and Lecturers to determine whether there is significance differences in their class performance. These Professors, are known to have had longer teaching experiences alongside publications and have attained higher education. 
Additionally, a lecturer's ranking is normally one with a medium term of service and has less publication to their credit. These group of lecturers may include Doctor of Philosophy (PhD) and Masters' Degree holders. However the school also gives promotion to outstanding lecturers regardless of their ranks by appointing usually those with the long term of service and higher educational achievers.

\section{Problem Statement}

The formal implementation of student evaluation of their lecturers, mainly with a view to improve lecturer efficiency is not new in tertiary education. For many academic institutions to thrive on quality, it is very relevant to get feedback from recipient of the teaching, through course and lecturer evaluation by students. It cannot be underrated that lecturers know the use of such an exercise. Lecturers have continued to ask what the essence of the course and lecturer evaluation is. Therefore this mini project wants to find answers to the following;

- How a lecturer's knowledge does relates to his performance in class?

- Is there any significant differences in lecturers' methods of teaching in class and classroom performance?

- Is the attitude of lecturers in class different from his performance in class?

- What are the possible recommendations that help to improve teaching and learning in the Department of Business Administration, IIUM?

The investigation ought to be useful for educational planners, college councils, university lecturers and students. In an even broader context, the investigation can contribute towards better evaluation, better performances of lecturers, and a guide to staff promotions, institutional or departmental competitiveness and national wellbeing.

\section{Research Questions}

In this study the researcher attempts to answer the main question: How does the students of International Islamic University Malaysia, Department of Business Administration perceived their lecturers performance in the classroom? The above problem can be refined in twofold: Is there any significance difference between the general attitude of lecturers and performance in class? Does lecturers' knowledge in class affect students' performance? The last question is dealt with in terms of two relationships: the lecturer-subject matter, and the lecturer studentrelationship on campus. Details of the lecturer-subject matter are:

- General attitude of lectures in the Business Department

- Knowledge of the area of his/her specialization

- Methodology of his/her specialization with students.

- Recommendations provided by researcher

Details of lecturer-student relationship on campus are:

- General attitude to students

- Communicating lecture content with students

- Involving students cognitively in the lecture content

- Fairness in performance assessment 


\section{Objectives}

- To determine whether there is a significant relationship between the general attitude of lecturers in class and performance of lecturers in the classroom.

- To examine the relationship between knowledge of lecturers' in classroom and performance of lecturers in the classroom.

- To determine whether there is a significant relationship between the methodology of lecturers' in the classroom and the performance of lecturers in the classroom

- To provide recommendations that will help to improve teaching and learning at the Department of Business Administration.

\section{Literature Review}

Basically, education at all levels is based on effective teaching and learning. Effective teaching and learning are pointers to quality teaching performance and quality teachers which are all influencing components of a well-designed educational curriculum (Modebelu et al., 2013, Hanushek \& Rivkin, 2006). All over, lecturers are celebrated as the most influential human resources in our universities and the correlations between the students and them have been seen to be an essential element in the teaching and learning process. The most important reason is not only to help lecturers improve their skills in teaching, but also to assess how well they are performing in class. As lecturers are seen to be one of the most influential pillars of the University system, the quality of their performance must be systematically and continuously assessed.

Handshake and Wößmann (2007) observed that, the assessment of lecturers can be carried out in various ways as classroom observation, value-added models, analysis of classroom artefacts, self-report of practice and student evaluation of lecturers. Students evaluation of lecturers have so many advantages, thus, it is cost-efficient, it directly explore how a lecturer contributes to student learning process, and it shows the differences among lecturers in their contributions to student learning process. Lecturers who are seen to be less effective could be identified and provided with some assistance and be supported by the department.

Lecturers' performance is the ability of the lecturer to impart the relevant knowledge and skills necessary using appropriate strategies and methods always over a period of time to enhance students' learning and performance in class.

Corcoran et al., (2014) posited that, the quality of lecturers and lecturing are the most influencing components that affect students learning. Furthermore, lecturers' performance shows the ability of lecturers to perform effectively in the performance of their lecturing roles with high efforts and skills with regards to their subject matter using a sound methodological content that leads to student's effective learning and understanding. Therefore, to attain these in lecturing performance, lecturers should have the knowledge of different and appropriate methods, master their subject contents, understands students' strengths and weaknesses in order to carry out their lecturing responsibilities effectively and know the characteristics of good lecturing skills.

In fact, the students' role in the instructional process is equally essential as their perception could have an impact on their attitude towards certain courses. Allport (1935) sees 
perception as the way people assess others with who they are in contact. On the whole, students usually evaluate their school lecturers in areas such as knowledge of the subject matter, communication ability, the choice of appropriate lecturing methods and the general classroom management skills. A lecturer who is rated on these indices at high level is likely to enjoy the respect, confidence and admiration of the students based on their perception. Knowledge as the students think and perceive can help the lecturer to reflect upon and adjust the lecturing methods and strategies to enhance students' understanding and performance.

Conversely, students' perceptions of lecturers' performance have continued to be among the most vital barometer for assessing lecturing effectiveness (Scherer, et al., 2016). Studies examining students' perceptions are new, particularly at the universities. Previous researches have investigated the relationship between students' perceptions of the learning environment and its impact on learning outcomes (Abiola et al., 2013; Vonkova et al., 2015; Ibrahim, 2014; Hanover Research. 2013)

Ibrahim (2014) emphasized on the significance of students' perceptions of their lecturers' behaviours towards quality of lecturing and learning and concluded that the kinds of roles the lecturers assume have profound effects on the perceptions of students towards them and their self-concepts emphasized that students' learning is more affected by the perception of lecturing, than by the method of lecturing. Also, students preferred to seek assistance from their lecturers or classmates when encountering learning difficulties. From the general perspectives pertaining to performances of lecturers, Adediwura et al., (2007) and Dalley-Trim, (2007) clearly point out that, students' perceptions of the qualities of their lecturers results revealed that, students' perception of their lecturers' knowledge of subject matter, attitude to work and lecturing skills have a positive relationship on their students' academic performance.

\section{Conceptual framework}

Perception of students

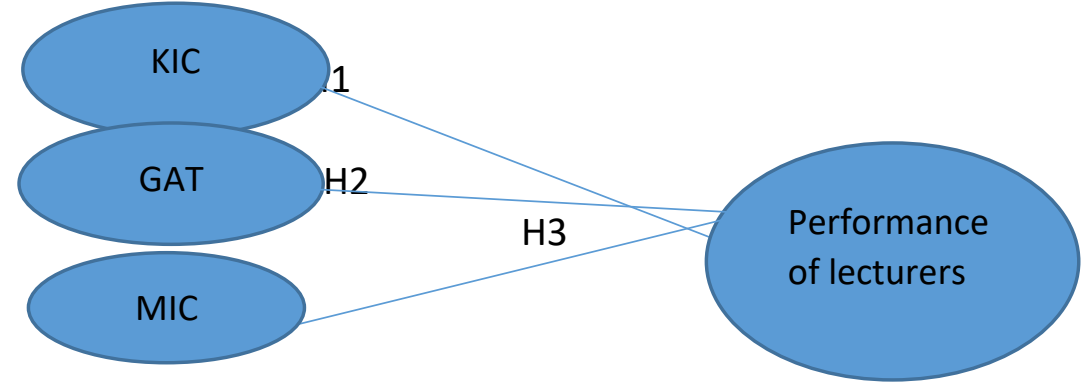

\section{Hypothesis Development}

Students' perceptions of lecturers' performance has continued to be among the most important measures for assessing lecturer's effectiveness (Scherer, 2016). Previous research have investigated the relationship between students' perceptions of the learning environment and its impact on performance (Abiola et al., 2013; Vonkova et al., 2015; Ibrahim, 2014; Hanover Research. 2013). 
Ibrahim (2014) emphasized on the significance of students' perceptions of their lecturers' behaviours towards quality of lecturing and learning which concluded that the kinds of roles the lecturers assume have profound effects on the perceptions of students towards them and their self-concepts emphasized that students' learning is more affected by the perception of lecturing than by the method of lecturing. Also, students preferred to seek assistance from their lecturers or classmates when encountering learning difficulties.

From the general perspectives pertaining to performances of lecturers, Adediwura et al., (2007) and Dalley-Trim, (2007) clearly point out that, students' perceptions of the qualities of their lecturers results revealed that, students' perception of their lecturers' in the area of knowledge of subject matter, attitude to work and the methodology have a positive relationship on their students' academic performance.

The study examines different latent variable modelling approaches that is confirmatory factor analysis (CFA), exploratory factor analysis (EFA) and the structural equation modelling (SEM), which are used to describe these individual perceptions with respect to their factor structure, measurement invariance and the relationships to selected educational outcomes (General attitude of lectures, knowledge of lectures and methodology used in class). In addition, the study found significant positive relations to these educational outcomes and creates different modelling approaches of individual students' perceptions of instructional quality and provides understandings into the nature of these perceptions from an individual differences perspective.

Chedi (2015) stressed on students' perceptions of teaching methodology and use of learning strategies from a general perspective as well. The study concluded that students preferred to use methodologies that enabled them to use time well and choose conducive learning environments.

Still from the general perspectives, pertaining to performances of lecturers, Abiola (2013) and Dauda (2016) clearly addresses the students' perceptions of the qualities or characteristics of their lecturers, the results revealed that students' perception of lecturers' knowledge of course content, attitude to work and teaching skills have a significant relationship on their lecturers' performance in class. Similarly, Vonkova (2015) compared students' perceptions of teacher's performance in classroom and highlighted the knowledge lecturers' exhibit in the classroom as one of the dimensions often measured in students' perception surveys and it was found to be one of the most predictive of students' achievement gains.

Additionally, researchers have generally concluded that there is a significant positive relationship between student's perception of lecturers' knowledge, attitude and methodologies as predictor of lectures' performance in classroom (Duyar \& Pearson, 2015). Student's perception of lecturers' performance has also been regarded as an important factor in predicting lecturers' performance and students learning; such as lecturers' knowledge, attitude and teaching skills and academic achievement (Dauda \& Umar, 2016). Empirically, several studies conducted have supported the students' perception of lecturers' performance and lecturers' performance in teaching relationship (Madike, 2015). 
However, these studies were done in different countries at different universities, but the researcher has identified that gap at IIUM's Business Administration Department. The researcher wishes to investigate the impact of students' perception on lecturers' performance as no research work has been done to uncover the perception of students in that department.

Therefore, it can be anticipated that lecturers' performance in lecturing as manifested by students' perception will lead to both lecturer improvement in role and extra roles performance in lecturing, students' understanding and academic achievements. Positive perceptions have been associated with deep learning approaches whereas negative perceptions with surface learning approach are recorded.

Based on the above relationships and the extensive literature review, the following hypothesis have been developed for the study:

$\mathrm{H} 1$ : There is a positive relationship between knowledge of lecturers in class and performance of lecturers in class.

$\mathrm{H} 2$ : There is a positive relationship between general attitude of lecturers and the performance of teaching in class.

H3: The teaching methods of lecturers has a direct relationship with their performance of teaching in class.

\section{Research Methodology}

This research covers data collection procedures, study design, sample size and the analysis of data. The study used exploratory factor analysis (EFA) and structural equation modelling (SEM). The selection of these techniques is based on the research objectives and the nature of existing data.

\section{Study Method/Design}

The aim of the study was to collect primary data from respondents (students). The purpose for the data collection was to analyze the data, interpret the results derive from the data analysis and eventually meet the objectives of the study. Before the data was collected, a meeting was held between the researcher and the respondents (students) through their respective lecturers to state in clear terms the purpose for the research, its objectives, and boundaries and to also assure them of the utmost confidentiality of their responses. Sufficient time was provided to respondents to complete and for collection of all questionnaires.

\section{Reliability and Validity}

To ensure reliability and validity of the data, the questionnaire was pilot tested with fifteen (15) students to ensure that the questionnaire depicts the purpose for which the study was been done. The pilot testing led to the modification of some of the items in the questionnaire. 
INTERNATIONAL JOURNAL OF ACADEMIC RESEARCH IN PROGRESSIVE EDUCATION AND

DEVELOPMENT

Vol. 10, No. 2, 2021, E-ISSN: 2226-6348 @ 2021 HRMARS

\section{Sample Technique}

The sampling method considered for the study was probability random sampling which ensures a non-zero chance of each student being sampled. The researcher collected views and opinions of students at the IIUM, Department of Business Administration using stratified random sampling technique. This often improves the representativeness of the sample by reducing sampling error. It also guard against an unrepresentative sample for example it prevented the researcher from selecting only final year students or only third year students in the Department of Business Administration .

The stratified random sampling technique was aimed at collecting views of both third $\left(3^{\text {rd }}\right.$ year) and final year ( $4^{\text {th }}$ year) students, therefore, the stratification was based on levels that are third year and final year students in the Department of Business Administration. The list of students in both two classes were obtained from their respective lecturers. Numbers were written on pieces of paper and folded to represent names on the sampling frame. The researcher kept pieces of papers into two different boxes, one box each containing numbers representing names of third year students and final year students. The researcher shuffled the pieces of papers and then selected the required sample size for each target group. Numbers picked were cross checked from the sampling frame to identify persons to be the respondents. Simple random technique was useful in the research because it ensures the presence of the key subgroup ( $3^{\text {rd }} \&$ $4^{\text {Th }}$ years) within the sample.

\section{Sample Size}

Sample size of this study was calculated using Cochran's (1977) method due to unlimited number of statistical population and five Likert point scale questionnaires. In using this method, the sample size calculation was based on the five Likert point scale items multiplied by the number of items in the questionnaire. Therefore, $20 \times 5=100$. The sample size for the research using Cochran's formula was 100. Stratified sampling method was adopted to categorized students into strata and simple random sampling technique was used to determine the respondents.

\section{Data Analysis}

The quantitative methods research design was used in this study. To asses' frequency of the data, the researcher employed SPSS AMOS tool to use descriptive analysis to represent tabulated data. Before the raw data was analyzed, the researcher first of all have to clean up errors associated with the data. Student performance Likert point scale which has been specifically developed for this study to elicit information from the students about their lecturers' performance in the lecture room.

Specifically, this study involved the use of Exploratory Factor Analysis (EFA), Confirmatory Factor Analysis (CFA) and the Structural Equation Modelling (SEM). First, a principal component analysis (PCA) with rotation was conducted to examine the factor structure of the 16 items, with multiple methods used to determine the number of factors underlying the data (e.g. eigenvaluegreater-than-one, screen plot, parallel analysis). Second, in order to see whether there were significant differences in the four factors extracted from the PCA in terms of knowledge in class, 
INTERNATIONAL JOURNAL OF ACADEMIC RESEARCH IN PROGRESSIVE EDUCATION AND DEVELOPMENT

Vol. 10, No. 2, 2021, E-ISSN: 2226-6348 @ 2021 HRMARS

general attitude of lecturers to work, methodology of lecturers in class and lecturers performance in class. Several analyses were conducted with the mean of the items loading on the factor as the dependent score. However, the results of the factor is seen in table 1 below.

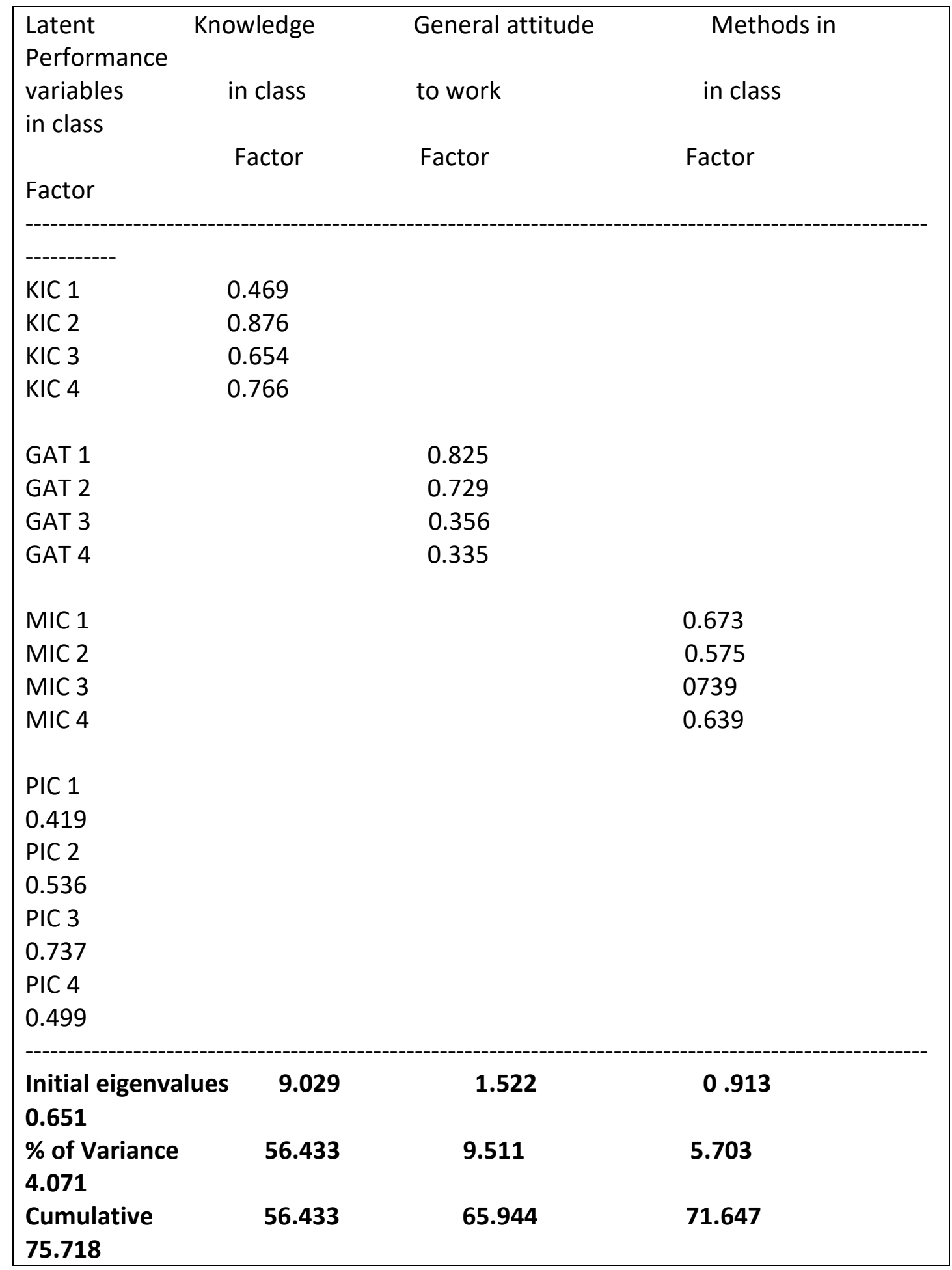

Table 1. Results of factor analysis 
Structural equation modeling is a multivariate statistical analysis technique that is used to analyze structural relationships. This technique is the combination of factor analysis and multiple regression analysis, and it is used to analyze the structural relationship between measured variables and latent constructs. This method is preferred by the researcher because it estimates the multiple and interrelated dependence in a single analysis. In this analysis, two types of variables are used: endogenous variables and exogenous variables. Endogenous variables are equivalent to dependent variables and are equal to the independent variable.

The Structural Equation Model (SEM) according Henseler et al. (2009) consists of two models. The first is the measurement model which represents how measured variables come together to represent constructs. It is also known as path analysis. Path analysis is a set of relationships between exogenous and endogens variables. This is shown by the use of an arrow. The measurement model follows the assumption of unidimensionality. The structural model also shows how constructs are related to each other. It is also called casual modeling because it tests the proposed casual relationships.

The various ways to assess fitment of measurement or the outer model are reliability (measured through composite reliability), convergent validity through average variance extracted (AVE) and factor loadings (Urbach \& Ahlemann, 2010). However, the Bartlett's sphericity test of 0.001 and Kaiser-Meyer-Olkin (KMO) of 0.91 in table 2 below verified the appropriateness of the sample.

Table 2.

KMO and Bartlett's Test

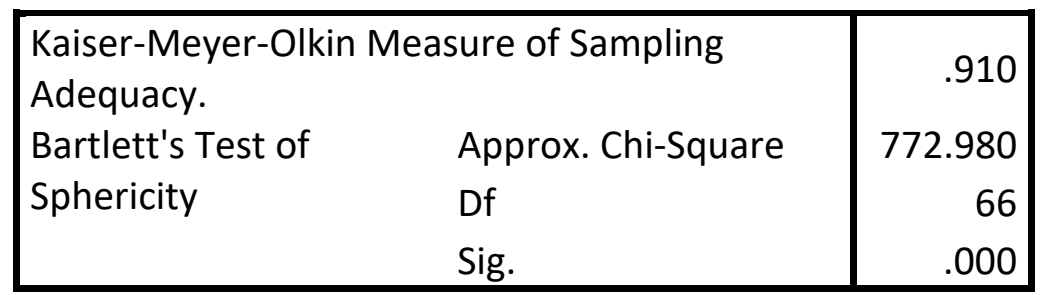

In table 1 above, all factor loadings are showing significant values. To evaluate the structural model the following fit indices were used: chi square, degree of frequency (df), Significant value (p), Normed chi square and the Root mean square error approximation (RMSEA).

Table 3. Reliability Statistics

\begin{tabular}{|r|r|}
\hline Cronbach's Alpha & N of Items \\
\hline .933 & 16 \\
\hline
\end{tabular}

Table 3 above indicates test measure of Cronbach alpha emerging as 0.933 . This test measures the consistency of the data.

\section{The Measurement Model}

An initial analysis of the measurement model indicated inadequate fit indices with coefficients lower than 0.5 (Kline, 1998). Factors which were loading below 0.70 were eliminated 
at the early stages of the modifications. To adjust the model, several counts of modifications were conducted and covariance were added to eliminate the errors. After that, the final model showed the appropriate fit indices of $p<.001$ the, following limits proposed by Hair et al. (2010). With respect to the reliability of the construct, the extracted variance and reliability were above the limit suggested. At the same time, with Cronbach's Alpha showing a value of 0.93 .

In fact, running a measurement model is also important prior to the baseline model, as it justifies whether the model defines the constructs adequately (Hair et al., 2010). Furthermore, it helps to define the construct validity. To seek the overall statistical fit for the measurement model or CFA, at least one of the measures from the absolute fit index, incremental fit index and parsimonious fit index is essential (Hair et al., 2010). Among the various measures, RMSEA, CFI and normed chi square ( $\times 2 / d f)$ are treated as the most reliable indices to be considered (Byrne, 2010). In all respects, revised CFA model confirms that the items belong to the constituting factors and attains the overall model fit.

Figure I below shows the initial and final fit index of the measurement model. As shown in Figure I, the Chi-square remained significant, degrees of freedom (df) shows $0.80, P$ values indicate $0.000(P<0.001)$ and the Root Mean Squared Error of Approximation (RMSEA) also emerged as 0.64 . This, however, shows an acceptable fit of the measurement model.

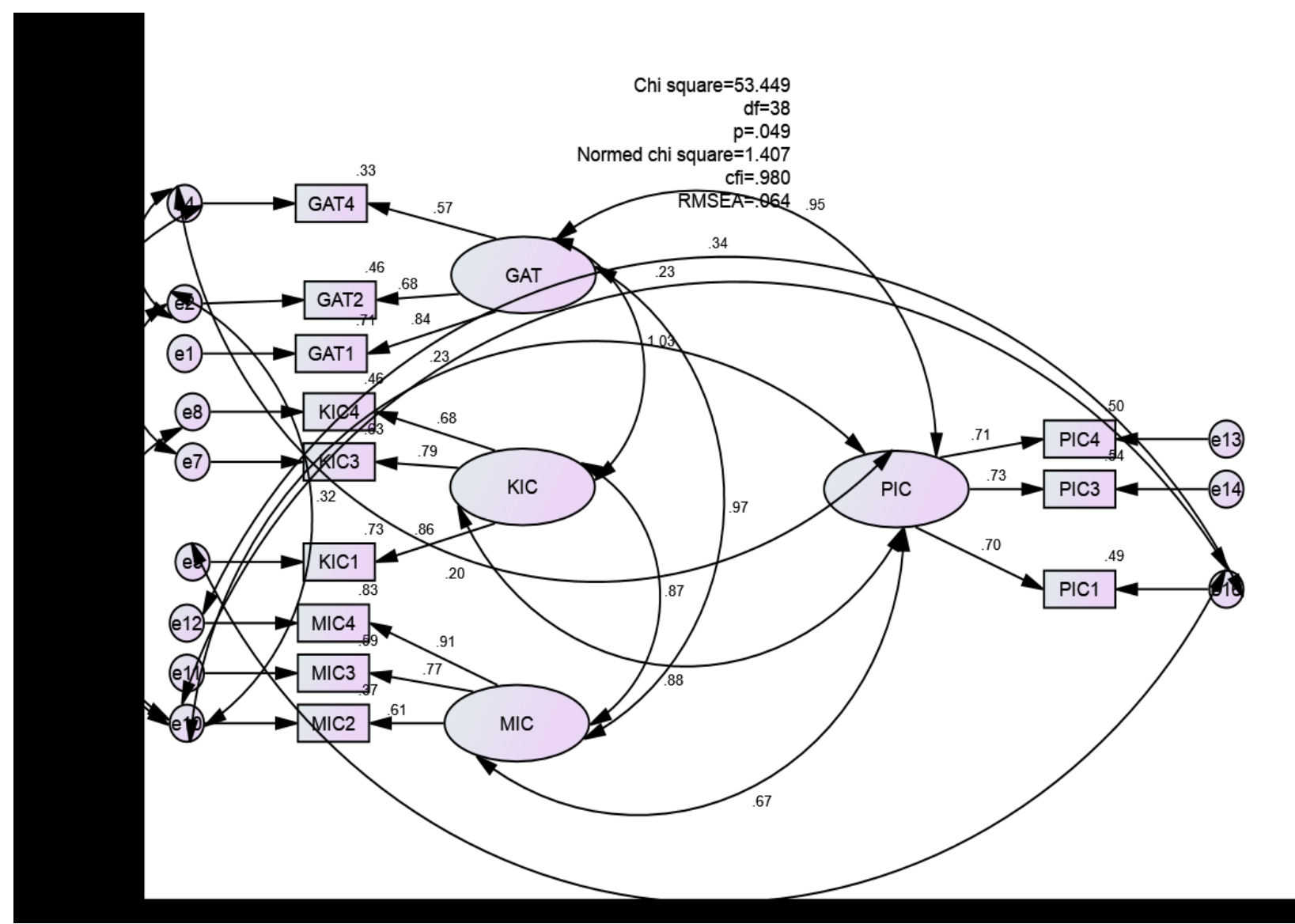

Figure 1. Structural model 
To find the relationship among the constructs, Structural justify model (SEM) was considered as a comprehensive approach. Unlike other analytical tools, SEM overall model fit where it calculates simultaneous relationship in a single frame (Hair et al., 2010). It shows the overall model fit, which the researcher can accept or reject from the single view.

Hence, based on the acceptable fit of the measurement model, the study continued to structural modelling with the established items of the constructs. Figure 2 depicts the revised measurement model of the study. After the satisfactory result of CFA, a full structural model was tested for its fitness and for testing of the hypotheses. In this case, various measures like: RMSEA, $\mathrm{CFI}$ and normed chi-square (x 2/df) were considered from the incremental, absolute, and parsimonious fit indices. Normed chi-square (x $2 / \mathrm{df})$ was used as the fundamental measures to assess the overall fit of the baseline model.

The researcher tested the scales for validity, dimensionality, and reliability using a confirmatory factor analysis (Hair et al., 2010). Unlike a confirmatory factor analysis (CFA) model where all of the latent variables are allowed to covary, this model shows a set of relationships among the latent variables and some of these relationships are directional (i.e., regression paths) and some are not (i.e., covariance). The model also specifies that any covariance among the three variables (General attitude of lecturers, knowledge of lecturers, and methodology in class) are entirely through the relationships with other. We can describe relationships among latent variables as covariance, direct effects, or indirect (mediated) effects. Covariance are analogous to correlations in that they are defined as non-directional relationships among independent latent variables. The researcher indicated them pictorially using double headed arrows.

Therefore, the lower the value, the better the model as the estimated and calculated value becomes closer at given " $p$ " value. Moreover, the comparative fit index or CFI is commonly used to measure the incremental fit of the study. The cutoff value for CFI is 0.90 is expected to be close to 1 . In this case it is 0.961 . Hence, this confirms to its fitness. On the other hand, the degree of freedom or the $\mathrm{df}$ is not performing as expected. At this point it is displaying a figure above the cut off limit of 3 , in this case it is 4.2. Among all the measures of absolute fit indices, the root mean square error of approximation or the RMSEA is widely used. Over here, the value is anticipated to be less than 0.085 for the absolute fit of the overall model. Here, the value of RMSEA emerged as 0.084 which affirms to a better fit of the model. Full structural model is presented in Figure 2 below, whereas the indices are highlighted in Table 4 below. 


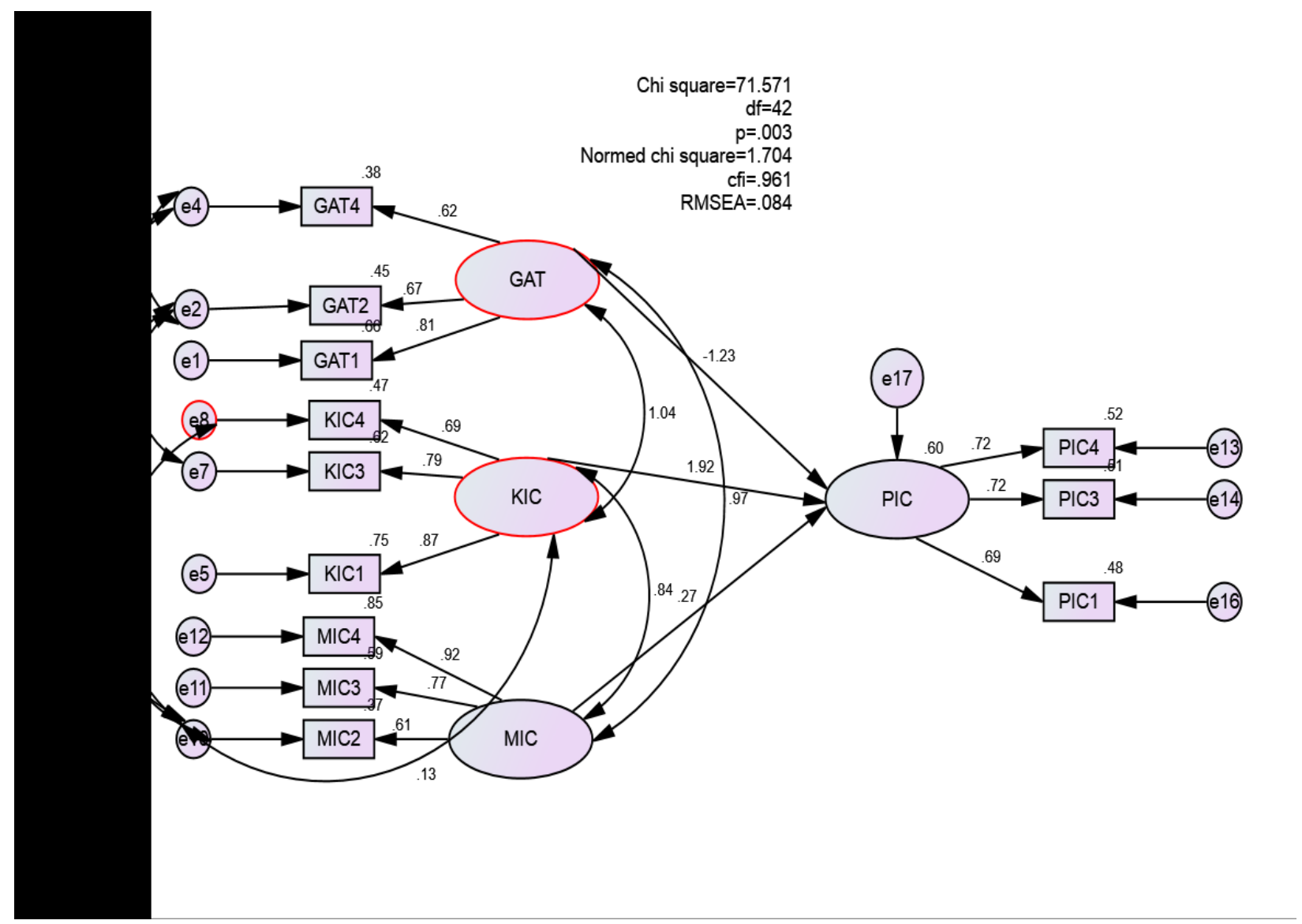

Figure 2.

Apart from using $\mathrm{CR}$ as a method to determine the significant and insignificant correlations, SEM practical significance (b value $>0.2$ ) and statistical significance ( $p$ value $<0.05$ ) are also widely used. In this research, $\mathrm{H} 1$ and $\mathrm{H} 3$ are supported with both practical and statistical significant values. However, H3 did not result in significance (see Table 4). To test the validity of the analysis, this study considers the output of the measurement model besides the baseline model. To account for the construct validity of the analysis, SEM needs to test discriminant and convergent face validity. Both factor loading (more than 0.70 in most of the cases) and reliability statistics of the result shows convergent validity. However, squared correlation matrix is significant at the level of 0.001 . Hence, this shows the satisfactory result of the discriminant validity of the analysis. Additionally, with the concern of strong theoretical support from the literatures, the face validity of the study is also established. 
Table 4. Results of hypothesis testing

\begin{tabular}{|c|c|c|c|c|c|c|}
\hline Structural path & $\begin{array}{l}\text { Hypothesis } \\
\text { Relationship }\end{array}$ & Estimates & SE & CR & $\mathbf{P}$ & S/NS \\
\hline GAT $\rightarrow \mathrm{PI} \mathrm{C}$ & $\mathrm{H} 1$ & -0.717 & 0.544 & -1.317 & 0.188 & Supported \\
\hline $\mathrm{KIC} \rightarrow \mathrm{PIC}$ & $\mathrm{H} 2$ & 1.065 & 0.389 & 2.74 & $* *$ & Not supported \\
\hline $\mathrm{MIC} \rightarrow \mathrm{PIC}$ & H3 & 0.130 & 0.266 & 0.491 & 0.624 & Supported \\
\hline
\end{tabular}

\section{Statistics}

Root mean square error of approximation (RMSEA)

Note:

$* *=\mathrm{P}<0.01$

GAT $=$ General attitude of teachers in \& outside classroom

$\mathrm{KIC}=$ Knowledge of teachers in class

MIC-= Methods of teaching in class

$\mathrm{PIC}=$ Performance of Teachers in class

\section{Results and Discussions}

Table 4 above shows the results of the hypothesis testing of three variables that is a positive relationship between general attitude of lecturers and performance of lecturers (H1). The second shows a positive relationship between the knowledge of lecturers and their performance in the classroom ( $\mathrm{H} 2)$, and the last is a positive relationship between methodology of lecturers in the classroom and performance of lecturers in the classroom (H3). According to Hair (2010), the threshold for either accepting or rejecting a relationship between two variables is when the $P$ value is greater than $0.05(P>0,05)$ or $P$ vales less than $0.05(P<0.05)$.

Hence, the results in table 4 above shows that, there is no significant difference between attitude of lecturers and performance of lecturers in the classroom and therefore $\mathrm{H} 1$ is supported 
with $P$ value of 0.188 that is, $P>0.05$. Again, there is also no significant difference between the methodology used in the class by lecturers and performance of lecturers in the classroom. Hence, $P$ value of 0.624 that is $b>0.2$ is also supported. However, the study further reveals that, there is significant difference between knowledge of lecturers and classroom performance. This means that, $\mathrm{H} 2$ relationship is significant and therefore not supported. $\mathrm{H} 2$ shows a value of $\mathrm{P}$ as 0.006 that is $\mathrm{P}<0.05$.

\section{Conclusion and Recommendations}

The study produces an important milieu for the lecturers in the Department of Business Administration at the International Islamic University Malaysia to uncover the underlying factors behind the perception of students on the performance of lecturers. The study shows that, students have a perception on the knowledge of lecturers with regards to some of the courses they teach. Some of the lecturers are not able to exhibit their knowledge by expressing themselves well for the students to better understand and appreciate what they are being taught in the classroom.

However, a majority of the lecturers according to the study are performing to the expectations of the students. The methodology or strategies of teaching students are quite good and the lecturers are able to conduct themselves well before the students and they are also available for consultations outside the normal class hours in their offices.

The reasons for the students rejecting $\mathrm{H} 2$ could possible mean that, some of the lecturers, despite the knowledge they have acquired over the years in schools do not prepare themselves adequately before going to teach in the classroom. Again, it could also be that, such lecturers are not linking materials taught in class to practical and field applications. This can also be attributed to the new lecturers who have just joined the department for the first time to teach at the higher level. Such lecturers even though, they have the knowledge but they do not have the experience to express themselves in the classroom for the understanding of the students. According to the study, such lecturers are not able to explain difficult topics to students clearly.

The possible suggestion could be that, lecturers in the Business Department of the University need to undergo in service training, workshops, seminars to upgrade their knowledge of linking materials taught in the classroom to practical and field applications. Again, lecturers should also be encouraged not to underrate the students' intelligence, they should at all times prepare themselves adequately before going to the lecture room.

The aforementioned, according to this research, is only for the category of respondents researched, which in this case were third and fourth year students at the Department of Business Administration. However, it may be true for the other departments as well. Perhaps more research is required on the same topic by collecting data from all the departments in the University, irrespective of their faculties and courses. Future researchers may also choose the same model and collect data from the other departments to test for invariance. Furthermore, the addition of mediating variables, like quality of teaching and professional ethics may bring forward interesting findings. 
INTERNATIONAL JOURNAL OF ACADEMIC RESEARCH IN PROGRESSIVE EDUCATION AND

DEVELOPMENT

Vol. 10, No. 2, 2021, E-ISSN: 2226-6348 @ 2021 HRMARS

\section{Corresponding Author}

Zaireena Wan Nasir

IIUM Malaysia

Email: zaireena@iium.edu.my

\section{References}

Abiola, O.-O. F. (2013). Students' Perception of Teachers' Factors in the Teaching and Learning of English Language in Nigerian Secondary Schools. Journal of Educational and Social Research, 3(3), 173-179. doi: 10.5901/jesr.2013.v3n3p173

Adediwura, A. A., \& Tayo, B. (2007). Perception of teacher's knowledge, attitude and Teaching skills as predictor of academic performance in Nigerian secondary schools. Educational Research and Reviews, 2(7), 165-171.

Allport, G. W. (1935). Attitudes. In C. Murchiso (Ed.), A Handbook Social Psychology (pp. 798844). Worchester: Clark University Pres

Bernard, F. (1997). Knowledge expectations in teaching. South African Journal for Higher Education 11(1), 79-84

Brown, T. (2015). Confirmatory Factor Analysis for Applied Research. New York: The Guilfor Press.

Cahn, S. (1996). Saints and Scamp: Ethics in Academia. Totowa, NJ: Rowman \& Littlefield. study. Canadian Journal of Higher Education,, 35(2), 49-70.

Chang, Y. (2010). Students' Perceptions of Teaching Styles and Use of Learning Strategies (Master's thesis). Retrieved from

Chedi, J. M. (2015). Technical drawing/graphic skills acquisition for teaching and learning and challenges in technology education. Journal of Science, Technology, \& Education, 3(3), 128-133. http://trace.tennessee.edu/cgi/viewcontent.cgi?article

Dalley-Trim, L. (2007). Students' Observations and Perceptions of Teacher "Performances" in the Classroom. Australian Journal of Teacher Education, 32(1), 17-35.

Dauda, B., Jambo, H. E., \& Umar, M. A. (2016). Students' Perception of Factors Influencing Teaching and Learning of Mathematics in Senior Secondary Schools in Maiduguri Metropolis, Borno State, Nigeria. Journal of Education and Practice, 7(20), 114-122.

Donahue, J. M. (1994). Student perceptions of their teachers, their school, and themselves as Learners (Doctoral dissertation). http://lib.dr.iastate.edu/cgi/

Duyar, I., Ras, N., \& Pearson, C. L. (2015). Analysis of teachers' task and extra-role performance under different autonomy regimes. International Journal of Productivity and Performance Management, 64(4), 499-522. doi: 10.1108/ijppm-06-2013-0103

Goulden, N. R., \& Griffin, B. L. (1997). Comparison of University faculty and student beliefs about the meaning of grades. Journal of research and development in education., 31(1), 28- 7.S elf-Concepts in Lagos Metropolis. Journal of Teaching and Teacher Education, 2( $133-141.3$

Hair, J. F., Anderson, R. E., Tatham, R. L., and Black, W. C. (2010), Multivariate Data Analysis, 5th ed., Prentice Hall, New York, NY

Ibrahim, A. (2014). The Students' Perception of Teachers' Classroom Effectiveness on Their Self-Concepts in Lagos Metropolis. Journal of Teaching and Teacher Education, 2(2), 
INTERNATIONAL JOURNAL OF ACADEMIC RESEARCH IN PROGRESSIVE EDUCATION AND

DEVELOPMENT

Vol. 10, No. 2, 2021, E-ISSN: 2226-6348 @ 2021 HRMARS

133-141.

Kline, R. B. (1998), Principles and Practice of Structural Equation Modeling, The Guilford Press, New York, NY.

MacGregor, J. (1993). Learning self-evaluation Challenges for students. New Directions for teaching and learning , 56, 35-46 mit, A. (1998). Fundamental pedagogics (B. Ed) study guide for DFP 401-M. Pretoria University of South Africa

Madike, V. N. (2015). Student Perceptions of Biology Teachers' Interpersonal Teaching Behaviors and Student Achievement (Doctoral dissertation). Retrieved from http://scholarworks.waldenu.edu/cgi/

Morton, P. (1997). Student evaluation of teaching. Nursing Outlook , 35(2), 86-88.

Modebelu, M. N., \& Nwakpadolu, G. M. (2013). Effective Teaching and Learning of Agricultural Science for Food Security and National Sustainability. Journal of Educational and Social Research, 3(4), 161-170. doi: 10.5901/jesr.2013.v3n4p161

Research. (2013). Student Perception Surveys and Teacher Assessments. https://ru.scribd.com/document/205141580/Student-PerceptionSurveys-and-Teacher-Assessments-Membership-2

Scherer, R., Nilsen, T., \& Jansen, M. (2016). Evaluating Individual Students' Perceptions of Instructional Quality: An Investigation of their Factor Structure, Measurement Invariance, and Relations to Educational Outcomes. Frontiers in Psychology, 7, 1-16. doi: 10.3389/fpsyg.2016.00110

Van-Rensburg, J. J. J., \& Visser, P. S. (1993). General Empirical Education (B.ed.) Stud Guide Pretoria: University of South Africa.

Vonkova, H., Zamarro, G., DeBerg, V., \& Hitt, C. (2015). Comparisons of Student Perceptions Of Teacher's Performance in the Classroom: Using Parametric Anchoring Vignette Methods for Improving Comparability. Retrieved from http://www.uaedreform.org/downloads/2015/05/comparisons-of-studentperceptions-of-teachers-performance-in-the-classroom-using-parametric-anchoringvignette-methods-for-improving-comparability.pdf

Vrey, J. D. (1993). The self-actualising educand. Pretoria: University of South Africa

Wachtel, H. K. (1998). Student evaluation of college teaching effectiveness: A brief review. Assessment \& Evaluation in Higher Education, 23(2), 191-212. 